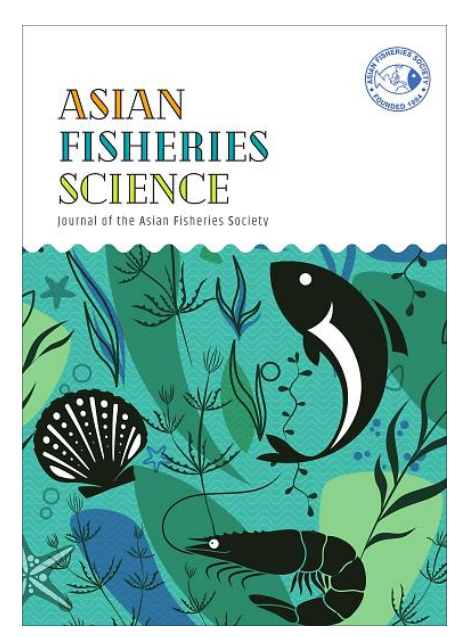

(ㄷ) Asian Fisheries Society

ISSN: 0116-6514

E-ISSN: 2073-3720

https://doi.org/10.33997/j.afs.2020.33.4.003

\title{
Multi-Criterion Classification and GIS: Application on Site Suitability for Green Mussel, Perna viridis (Linnaeus, 1758) Culture
}

\author{
DOMINIQUE MEDIODIA ${ }^{1, *}$, SHEENA GWEYN MAURIN', \\ ARMI MAY TORRECHILLA-GUZMAN', CARLOS BAYLON ${ }^{2}$ \\ IInstitute of Marine Fisheries and Oceanology, College of Fisheries and Ocean Sciences, University of the Philippines Visayas, Miagao, \\ Iloilo, Philippines 5023 \\ ${ }^{2}$ Institute of Aquaculture, College of Fisheries and Ocean Sciences, University of the Philippines Visayas, Miagao, lloilo, \\ Philippines 5023
}

*E-mail: dpmediodia@up.edu.ph |Received: 15/07/2020; Accepted: 30/11/2020

\section{Abstract}

Green mussel, Perna viridis (Linnaeus, 1758) is an important and inexpensive source of protein in coastal areas, and successful mussel culture is highly influenced by physico-chemical parameters. With the aid of geographic information system (GIS), the study was carried out to determine the suitability of Cañas Bay in the Philippines for green mussel culture. In situ physico-chemical parameters (temperature, salinity, dissolved oxygen, and $\mathrm{pH}$ ) were measured from 10 sampling stations on a weekly interval from May 2015 to April 2016 and analysed using weighted overlay analysis in ArcGIS 10.1 to evaluate its suitability. Spatial distributions of the different physico-chemical parameters revealed that $71.08 \%$ of Cañas Bay was found to be highly suitable based on temperature, $65.21 \%$ for salinity, $100 \%$ for dissolved oxygen, and $64.81 \%$ for $\mathrm{pH}$. A total of 715.71 ha in Cañas Bay can be utilised as an expansion area for growing green mussel $P$. viridis. It was further validated by the increasing growth of green mussel cultured in the specific location of the bay identified as highly suitable. This study revealed the importance of GIS in identifying suitable sites for expansion that can also be applied to different aquaculture commodities.

Keywords: geospatial technologies, multi-criteria suitability assessment, fisheries and aquaculture management

\section{Introduction}

The use of geographic information system (GIS) and techniques to analyse the spatial characteristics of ground-truth data have become an integral component for fisheries management worldwide. GIS is also used for fisheries management planning (Close and Brent Hall, 2006), terrestrial ecosystem (Clevenger et al., 2002), identifying the extent of anthropogenic activities in marine protected areas (MPAs) (Bendell and Wan, 2011), and disaster management (Adeleke et al., 2013). GIS is also used to determine fishing efforts by trawls (Murawski et al., 2005), record spatiotemporal distribution of marine fishes (Dineshbabu et al., 2015), and assess water resources for inland fisheries and aquaculture (Ingole et al., 2015). GIS also provides more comprehensive and integrated treatment for site selection than manual analytical technology (Aguilar-Manjarrez and Ross, 1995). Geographic information system has been used to identify suitable sites for mollusc farming as a spatial decision support tool for aquaculture (Nath et al. 2000). Buitrago et al. (2005) used a single site selection technique to identify suitable sites for mangrove oyster, Crassostrea rhizophorae (Guilding, 1828) in Margarita Island, Venezuela. A GIS-based habitat suitability model for commercial yield estimation of Manila clam, Tapes philippinarum (Adams and Reeve, 1850) in Mediterranean coastal lagoon was developed by Vincenzi et al. (2006). Longdill et al. (2008) identified sites for Perna canaliculus (Gmelin, 1791) in aquaculture management areas in New Zealand using GIS and these models were used for the identification of sites for green mussel culture. In the Valdivia River estuary in Chile, GIS was used to identify suitable sites for mussel, taking into consideration the regulatory and social constraints, growth and survival factors, physical factors, product quality factors, environmental sensitivity zones, water, and sediment using multi-criteria evaluation (Silva et al., 2011).

In the Philippines, GIS-based models were used to 
identify seaweed culture areas for sustainable farming and the identification of possible expansion areas (Trondillo et al., 2016). GIS is applied for the conservation of marine resources through the creation of MPA's (Rubec et al., 2009), improvement of coastal aquaculture development zones (White et al., 2013), and mapping coastal aquaculture and fisheries structures (Travaglia et al., 2004). GIS can also treat many spatial components simultaneously compared to other techniques (de Graaf and Jenness, 2003), making it an appropriate tool to use for information with many spatial components like in the field of fisheries. However, the application of GIS in fisheries and aquaculture is still limited (de Graaf and Jenness, 2003) and its potential is not yet maximised. Therefore, there is a need for a more comprehensive approach to use GIS that will highlight its importance as support to enhance aquaculture management.

The use of GIS in fisheries and aquaculture will be of great importance to improve decision-making, specifically on the geographical allocation of various aquaculture commodities. One of the commodities currently being given importance worldwide is the production of green mussel, Perna viridis (Linnaeus, 1758). The volume of green mussel production in the Philippines in 2018 was estimated at 26,300 metric tonnes which had increased by $36.93 \%$ from 2017 (Philippine Statistics Authority, 2018). However, there has not been a significant increase in the production of green mussel in the past decade due to some factors such as sanitary contaminants (Smaal, 2002), drastic temporal fluctuations in water temperature (Firth et al., 2011), salinity fluctuations (Smaal, 2002), periodic harmful algal blooms causing paralytic shellfish poisoning (Anderson, 1989), and predation (Baumiller et al., 2008). To provide an adequate response to the problem of low production of green mussel, it is important to expand and utilise suitable areas for green mussel production. This can be achieved through the use of GIS where quick and reliable information can be displayed visually for better management of aquaculture areas.

This study aims to identify expansion area for green mussel P. viridis based on physico-chemical parameters (i.e. temperature, salinity, $\mathrm{DO}$, and $\mathrm{pH}$ ) using GIS and develop a suitability model applicable to areas with potential for green mussel culture and thematic maps of suitable sites that can be of significant help to the local community and the mussel industry. This also highlights the potential of Cañas Bay as a model site in identifying expansion areas that may help in addressing issues on food security by improving green mussel production in the country.

\section{Materials and Methods}

\section{Physico-chemical parameters}

The study site is an enclosed bay with no existing culture of green mussel located at Cañas Bay, Barotac
Viejo, Iloilo, Philippines $\left(11.0604^{\circ}-11.02275^{\circ} \mathrm{N}\right.$; $\left.122.9286^{\circ}-122.9303^{\circ} \mathrm{E}\right)$. The selection of this site was based on the natural presence of bivalves such as oysters and clams and the sandy-muddy substrate of the area, which suggests its potential for growing green mussel. The feasibility of the area for easy transport of equipment and personnel from the laboratory to the site was also considered. Ten sampling stations were randomly selected to represent the entire bay at depths ranging from 1-4 $\mathrm{m}$ (Fig. 1).

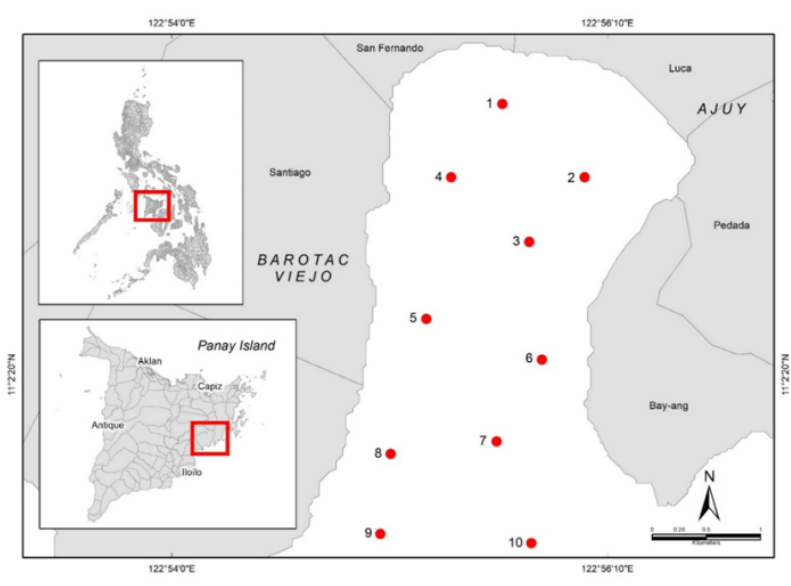

Fig. 1. Location of ten sampling stations in Cañas Bay, Barotac Viejo, Iloilo, Philippines where physico-chemical parameters were measured for one year and were used for the multi-criterion evaluation to determine the suitability of the area for green mussel Perna viridis culture.

The predetermined sampling stations were projected and divided into grids using Google Earth (2015). Points were then marked using Global Positioning System (GPS) (Etrex 20, USA) and were used as basis during the data collection. In situ physico-chemical parameters such as temperature $\left({ }^{\circ} \mathrm{C}\right)$, salinity (ppt), DO (mg. $\left.\mathrm{L}^{-1}\right)$ and $\mathrm{pH}$ were measured at one meter below the water surface using a multi-functional environmental meter (YSI Professional Plus, USA). Sensors were calibrated every sampling period. Monthly sampling was done (8:00-10:00 am in the morning) for 12 months, from May 2015 until April 2016. Chlorophyll a was measured for three months using a spectrophotometer but was not included in the final model. General methods in identifying a suitable site are presented in Figure 2.

\section{Criteria for site-suitability}

The criteria for identifying suitable sites were developed based on expert's knowledge and published articles. Temperature, salinity, DO, and $\mathrm{pH}$ were proven to affect the growth and survival of green mussel, making these parameters ideal for the model. These parameters were considered as the primary components to determine the physical carrying capacity and the suitability of the area. Weights 
assigned in identifying areas suitable for mussel culture were based on the general agreement among experts on green mussel during the focus group discussion (FGD) as adapted from Tan and Ransangan (2016) with minor changes. The most important water quality parameters which are temperature and salinity were given the highest score compared to $\mathrm{DO}$ and $\mathrm{pH}$. Factor scores were objectively based on published articles and real data but were considered partly subjective because it was dependent upon the decisions made during the FGD. W temp denotes average temperature, $W_{\text {salinity }}$ for average salinity, $W_{p H}$, and $W_{D O}$ for average $\mathrm{pH}$ and average dissolved oxygen, respectively.

$$
\begin{aligned}
& \text { Suitability }=0.30 W_{\text {temp }}+0.30 W_{\text {salinity }}+0.20 W_{p H}+ \\
& 0.20 W_{D O}
\end{aligned}
$$

Optimum level set for temperature ranged from 25 to $33^{\circ} \mathrm{C}$; salinity 25-33 ppt; pH 7-8 and dissolved oxygen 5-7 mg. $\mathrm{L}^{-1}$ (Table 1). Based on the 10-point scale rating adapted from Tan and Ransangan (2016), suitability was divided into highly suitable, moderately suitable and not suitable (Table 2). Categories were interpreted into highly recommended for mussel culture, moderately suitable area may support green mussel culture but are not recommended, and areas that are not suitable to support mussel culture.

\section{GIS application to assess site suitability}

Data processing, thematic maps development, and GIS analysis were done using Arcmap 10.1. Topographic base maps were downloaded from the website of National Mapping and Resource Information Authority (NAMRIA) and projections were changed to Universal Transverse Mercator (UTM)Zone 51, WGS 84. A geoprocessing model was made using the model builder tool of ArcMap 10.1. Data used were the average physico-chemical parameters (temperature, salinity, dissolved oxygen, and $\mathrm{pH}$ ) of each station in Cañas Bay within a period of one year. Weights were assigned to each parameter according to its importance. Raster data of each parameter were reclassified into values of 1 to 3 from 1 , being the least suitable, 2, moderately suitable, and 3, most suitable. In order to determine the area suitability, the reclassified raster data were integrated using a measurement scale in the weighted overlay tool.

\section{Site verification}

To validate the identified suitable area, mussel culture was done in one portion of Cañas Bay $\left(11.05613^{\circ}-11.05649^{\circ} \mathrm{N}\right.$ i $\left.122.9248^{\circ}-122.9289^{\circ} \mathrm{E}\right)$ identified as highly suitable. Mussel spats $(3-4 \mathrm{~cm})$

Table 1. Rating scale and weighted value of physico-chemical parameters applied for assessing the suitability of Cañas Bay, Philippines for Perna viridis culture.

\begin{tabular}{lllll}
\hline Rating point & Temperature $\left({ }^{\circ} \mathrm{C}\right)$ & Salinity $(\mathrm{ppt})$ & $\mathrm{pH}$ & $\begin{array}{l}\text { Dissolved oxygen } \\
\left(\mathrm{mg} . \mathrm{L}^{-1}\right)\end{array}$ \\
\hline 10 & $25-33$ & $25-33$ & $7-8$ & $5-7$ \\
\hline 9 & $24-34$ & $22-35$ & $6.9-8.2$ & $4-8$ \\
\hline 8 & $23-35$ & $21-37$ & $6.8-8.3$ & $3.5-8.5$ \\
\hline 7 & $23-36$ & $19-38$ & $6.6-8.4$ & $3.0-9.0$ \\
6 & $23-37$ & $17-40$ & $6.5-8.5$ & $2.8-9.2$ \\
5 & $22-38$ & $15-42$ & $6.4-8.6$ & $2.6-9.5$ \\
4 & $21-39$ & $14-44$ & $6.3-8.7$ & $2.0-9.7$ \\
3 & $20-40$ & $10-50$ & $6.2-8.8$ & $1.8-10.0$ \\
2 & $19-41$ & $5-55$ & $6.1-8.9$ & $0-1.8$ \\
1 & $18-42$ & $0-65$ & $6.0-9.0$ & $<0$ \\
\hline Weighted value & 0.3 & 0.3 & 0.2 & 0.2 \\
\hline
\end{tabular}

Table 2. The suitability categories of sites for bivalves farming adapted from Sallih, 2005; Salmon and Kingzett, 2002; Tan and Ransangan, 2016 with slight modifications on the remarks and on the rating points used.

\begin{tabular}{lll}
\hline Rating point & Site suitability & Remarks \\
\hline 1.0-3.0 & Poor & The site is not suitable for green mussel culture \\
3.1-7.0 & Moderate & The site is moderately suitable for green mussel culture \\
7.1-10.0 & Excellent & The site is highly suitable for green mussel culture \\
\hline
\end{tabular}


were attached to the rope at 200 spats. $\mathrm{m}^{-1}$ and hanged in a $6 \mathrm{~m} \times 6 \mathrm{~m}$ raft for 6 months from November to April. Thirty mussels were randomly selected for growth measurement. Individual length (cm) and weight $(\mathrm{g})$ were measured using a Vernier calliper and an analytical balance (Shimadzu, Japan), respectively. The average monthly growth rate (MGR = $\%$ month) in length and weight was expressed as percentage increase in initial stock per month for each replicate using the formula:

$M G R_{L}$

$=[\ln ($ Final length/Initial length/Duration of culture $)]$ $\times 100$

$M G R_{w}$

$=[\ln ($ Final weight $/$ Initial weight $/$ Duration of culture $)]$ $\times 100$

\section{Statistical analysis}

Statistical analysis was performed with SPSS Version 16.0 statistical software package. Data were expressed as means \pm standard deviation (SD). Comparison between months for physico-chemical parameters and mussel growth were performed using one-way analysis of variance (ANOVA) with $95 \%$ level of confidence.

\section{Results}

\section{Physico-chemical parameters in Cañas Bay}

The monthly average values of physico-chemical parameters in the study site are presented in Figure 3. The average temperature was $29.03 \pm 1.47^{\circ} \mathrm{C}$ (26.53$\left.31.33^{\circ} \mathrm{C}\right)$, average salinity of $33.29 \pm 1.37 \mathrm{ppt}(30.03-$ $35.25 \mathrm{ppt})$, average DO of $5.71 \pm 0.4 \mathrm{mg} . \mathrm{L}^{-1}(5.11-6.59$ $\left.\mathrm{mg} . \mathrm{L}^{-1}\right)$, and average $\mathrm{pH}$ of $7.96 \pm 0.1$ (7.80-8.10). A significantly high temperature in the months of April to June $(P<0.05)$ and a gradual decrease from July to November were observed. Significantly low salinity was recorded in November $(P<0.05)$. However, $\mathrm{pH}$, and dissolved oxygen showed no significant differences between months $(P>0.05)$. Chlorophyll a of Cañas Bay measured for the first three months of sampling ranged from 7.1 to $8.1 \mu \mathrm{g} . \mathrm{L}^{-1}$ but was no longer included in the model (Fig. 3). All parameters measured were within the optimum range for mussel growth.

\section{Assessing the suitability of Cañas Bay for Perna viridis culture using GIS}

Using weighted overlay function of ArcGIS, $71.08 \%$ of the area was found to be highly suitable based on temperature, $65.21 \%$ based on salinity, $100 \%$ on DO, and $64.81 \%$ based on $\mathrm{pH}$. As shown in Figure 4, sampling stations 1-7 were found to be highly suitable areas for green mussel culture, whereas sampling stations 8-10 were categorised as moderately suitable areas. Highly suitable areas covered a large portion of Santiago and Fernando in Barotac Viejo and Luca, Pedada, and Bay-ang in Ajuy, Iloilo (Fig. 4). The layered spatial distributions of environmental factors (i.e. temperature, salinity, $\mathrm{DO}$ and $\mathrm{pH}$ ) revealed a total of 715.71 ha $(65.21 \%)$ of Cañas Bay which can be utilised as a new expansion area for green mussel culture (Table 3). There was no portion of the bay that was identified as not suitable.

The site selection model using weighted overlay evaluation confirmed the suitability of Cañas Bay for $P$. viridis farming, which was validated by the increasing growth of green mussel that reached the marketable size and by the presence of wild spats attaching on the raft. After six months, an average length of $7.18 \mathrm{~cm}$ and weight of $13.89 \mathrm{~g}$ from $3.75 \mathrm{~cm}$ length and $3.99 \mathrm{~g}$ weight were recorded (Fig. 5). There was an average increase of $3.43 \mathrm{~cm}$ in length and $9.9 \mathrm{~g}$ in weight which showed a significant increase $(P<$ $0.05)$ from the initial stock size. Average MGR w was $114.22 \%$ and $M_{\text {GR }}$ was $54.43 \%$. Mussel spats attaching in the raft were also observed during the culture period.
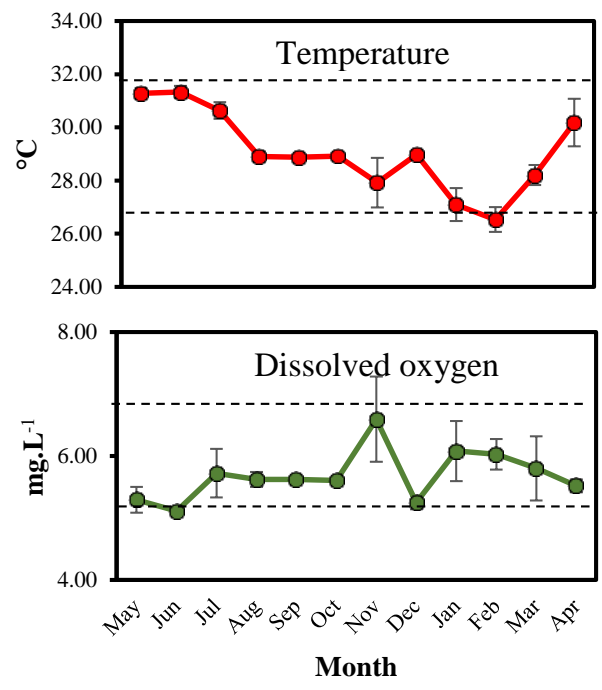

Month
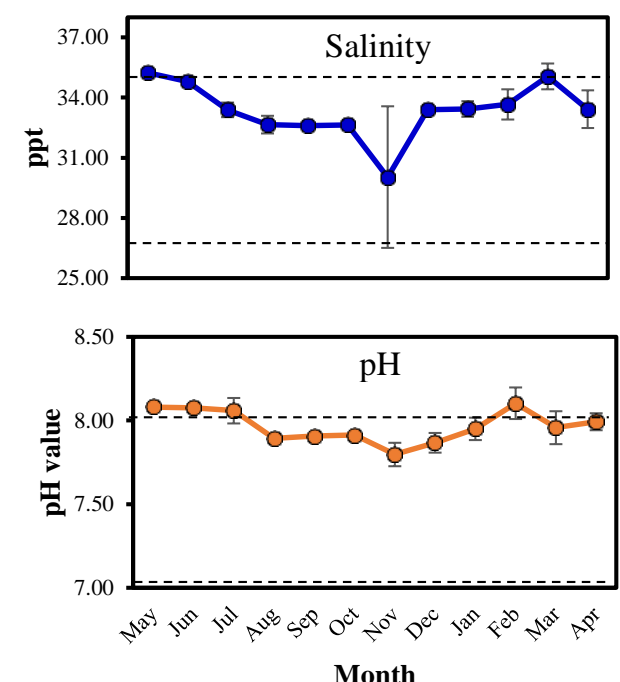

Fig. 3. Monthly average physicochemical parameters in Cañas Bay, Barotac Viejo, Iloilo, Philippines. Horizontal broken lines show the maximum and minimum parameters optimum for the growth of Perna viridis. 

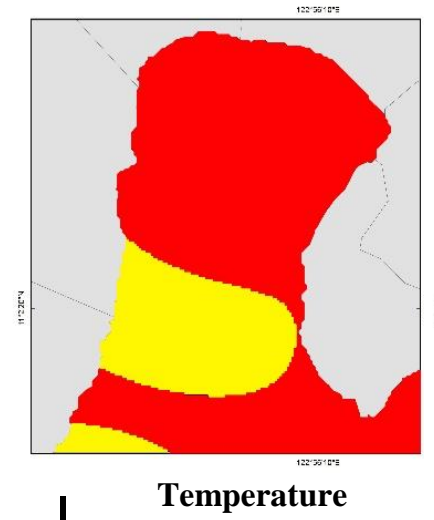

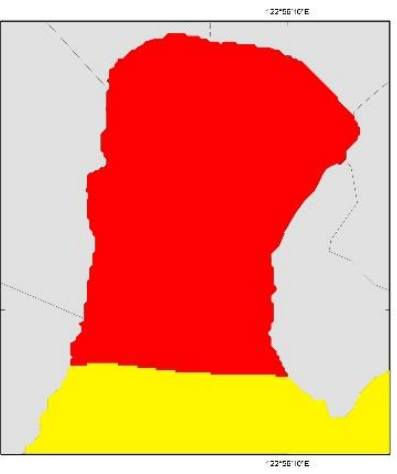

Salinity

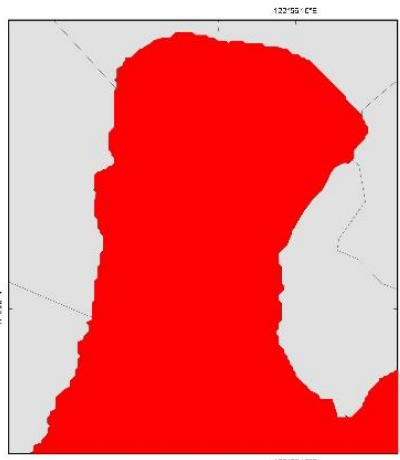

Dissolved Oxygen

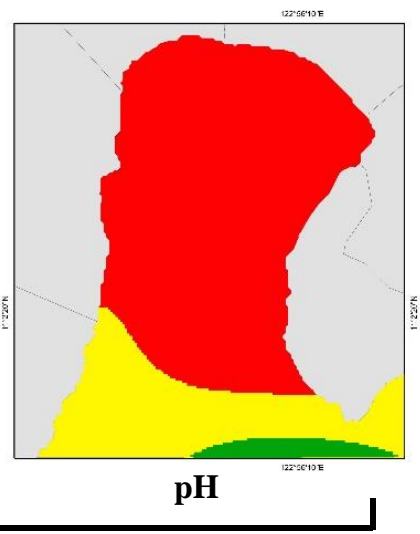

\section{Multi-criteria evaluation}

$122^{\circ} 54^{\prime} 0^{\prime \prime} \mathrm{E}$

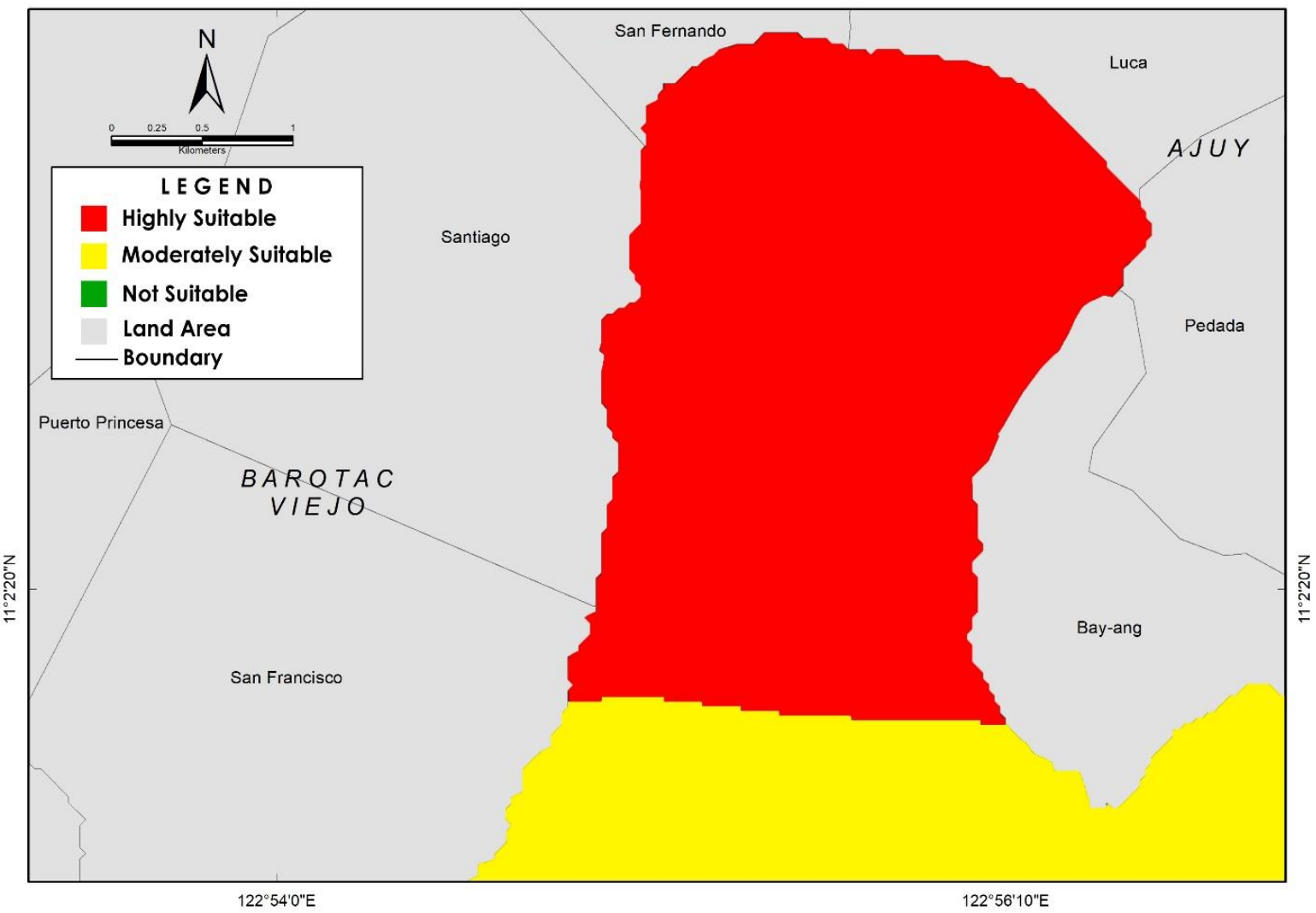

Fig. 4. Suitability map of Cañas Bay for Perna viridis culture based on based on the multi-criteria evaluation model for temperature, salinity, DO, and pH developed using geographic information system.

Table 3. Area (ha) and proportion (\%) of Cañas Bay suitable for Perna viridis culture based on the multi-criteria evaluation model.

\begin{tabular}{llllllc}
\hline \multirow{2}{*}{ Water quality parameters } & \multicolumn{2}{l}{ Highly suitable } & \multicolumn{2}{l}{ Moderately suitable } & \multicolumn{2}{l}{ Not suitable } \\
\cline { 2 - 7 } & ha & $\%$ & ha & $\%$ & ha & $\%$ \\
\hline Temperature $\left({ }^{\circ} \mathrm{C}\right)$ & 780.20 & 71.08 & 279.83 & 25.50 & 37.60 & 3.42 \\
Salinity (ppt) & 715.71 & 65.21 & 381.91 & 34.79 & - & - \\
pH & 711.40 & 64.81 & 289.26 & 26.35 & 96.96 & 8.83 \\
Dissolved oxygen $\left(\mathrm{mg.L}^{-1}\right)$ & $1,097.62$ & 100 & - & - & - & - \\
Overall Suitability & 715.71 & 65.21 & 381.91 & 34.79 & - & - \\
\hline
\end{tabular}

Note: - showed no value. 

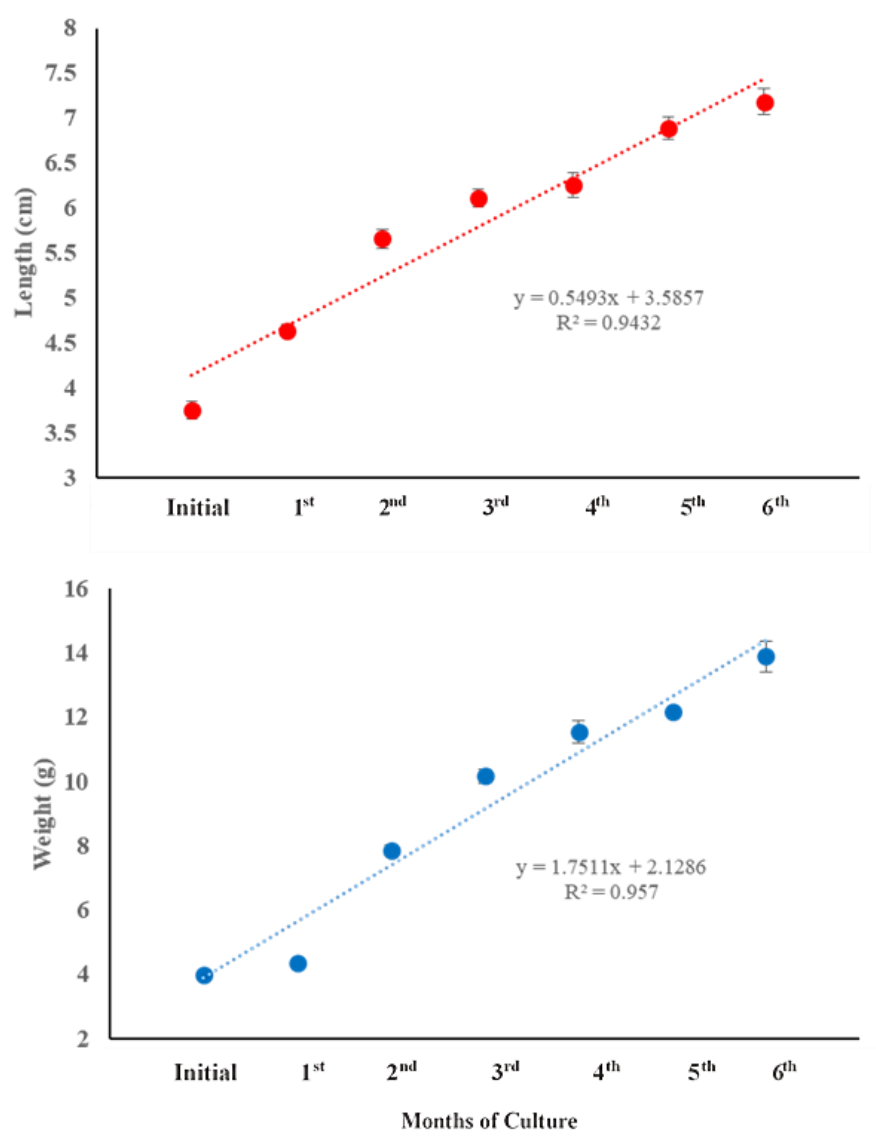

Fig. 5. Monthly average growth in length (a) and weight (b) of green mussel Perna viridis in Cañas Bay for 6 months of culture. Vertical bars show standard error $(n=30)$.

\section{Discussion}

The decrease in the production of fishery products such as the green mussel due to various factors becomes a global problem that needs an immediate response. These can be attributed to mass mortalities experienced by other countries and depleted stocks as observed in the Philippines. One of the possible solutions is to identify a new expansion area for culture, where physico-chemical parameters are suitable for green mussel. Favourable conditions for mussel growth are an important factor to consider before establishing mussel culture (Longdill et al., 2008). In this study, the potential of Cañas Bay, Iloilo as a new expansion site was determined with the use of GIS. The present model in this study is limited only to the physico-chemical parameters such as temperature, salinity, DO, and pH. Green mussels are known to have sensors which detect physical and chemical changes in waters (Wong and Cheung, 2003) that could affect growth and survival. Sivalingam (1977) reported that green mussels could tolerate temperatures from $26^{\circ} \mathrm{C}$ to $32{ }^{\circ} \mathrm{C}$ that is not far from the reports of Tan and Ransangan (2014) showing tolerance ranges of $27-32^{\circ} \mathrm{C}$. Temperatures less than $12^{\circ} \mathrm{C}$ (Segnini de Bravo et al., 1998; Benson et al., 2001) and above $37^{\circ} \mathrm{C}$ (Chung and Acuña, 1981; Seginini de Bravo et al., 1998) were proven to be lethal for mussels. In addition, reports of Aypa (1990) on the salinity (27-33 ppt) tolerance of green mussel, Tan and
Ransangan (2014) on the DO tolerance (7.9-8.2 ppm), and Layugan et al. (2018) on the pH tolerance (7-8) were considered in the model.

Generally, minimal fluctuations were observed in the physico-chemical parameters measured in Cañas Bay and the average monthly values were all within the tolerance level as reported by various authors. The Philippine Atmospheric Geophysical and Astronomic Services Administration (PAGASA) classified December to May as months of dry season while June to November as months of the rainy season. The high temperature in Cañas Bay can be due to higher solar radiation during the months of April to June. A sudden decrease in salinity from 32.64 to 30.03 ppt was influenced by the freshwater dilution during heavy rainfall in November (Saxby, 2002). Drastic temporal fluctuations in the water had been associated with the mortality event in Marudu Bay, Malaysia, which wiped out green mussels (Firth et al., 2011). A decrease in salinity in the Atlantic coast also resulted in high mortality and poor growth performance of $P$. viridis (Smaal, 2002). However, reports revealed high salinity tolerance of mussels which ranged from 27 ppt to 35 ppt (Aypa 1990) and salinity as low as 16 ppt (Sundaram and Shafee, 1989). Salinity below $5 \mathrm{ppt}$ could be lethal to P. viridis (Coeroli et al., 1984). A gradual decrease of salinity to as low as 6 ppt can still support the growth of mussels but abrupt changes will result in low survival (McFarland et al., 2014). Tan 
and Ransangan (2014) reported that the ranges for optimum dissolved oxygen and $\mathrm{pH}$ for mussel were 4$8 \mathrm{mg} . \mathrm{L}^{-1}$ and $7.9-8.2$, respectively. However, $\mathrm{pH}$ values between $\leq 5.0$ and $\geq 8.9$ may support culture but were not recommended. This study revealed that physicochemical parameters such as temperature, salinity, $\mathrm{DO}$, and $\mathrm{pH}$ in all sampling stations in Cañas Bay over a 12 -month period were within the optimal ranges to support $P$. viridis culture. The chlorophyll a measured in the first 3 months of the sampling $\left(7.1-8.1 \mu \mathrm{g} . \mathrm{L}^{-1}\right)$ were higher than the range set by Sivalingam (1977) which was 3.5-5.2 $\mu \mathrm{g} . \mathrm{L}^{-1}$. This indicates that the food available in Cañas Bay is adequate to sustain green mussel culture. It was further supported by the significant growth of green mussel that survived for 6 months. Factors such as environmental and institutional issues, culture requirements, potential impacts, users and uses of the marine environments (Longdill et al., 2008) must also be considered in the model. In addition, a study of Tan and Ransangan (2016) recommended that green mussel culture must be done in areas near the mouth of the bay. Spatiotemporal variations should also be considered and the suitability results must be updated, reviewed, and revised over time. Assigning weights to different physico-chemical parameters is a critical decision factor in the site suitability assessment. Relevant published literature and opinions from experts should be thoroughly studied and considered.

The model derived from this study is a significant development in achieving rapid and effective assessment for green mussel cultivation. This model can be applied to other bivalves but the tolerance of each species must be properly measured. The model was then validated by the significant increase in the growth of green mussel cultured in Cañas Bay. An average length of $7.18 \mathrm{~cm}$ and weight of $13.89 \mathrm{~g}$ in this study was within the range reported by Vakily (1989) and Acosta et al. (2012) for P. viridis. It also had higher monthly growth in length, as compared to the report of Cheong and Chen (1980) which was $0.106 \mathrm{~cm}$ per month during the first six months of culture. These differences were influenced by the physico-chemical parameters of the culture site and the methods used for culture. Increasing the culture period to one year rather than the usual six months may also affect the growth of green mussel.

The development of this linear model for rapid assessment of the suitability of the area showed that GIS is a useful tool for green mussel culture site selection and can be of great use to the government agencies in developing their plans for the proper zoning of water resources in the Philippines and in other countries. Thematic maps developed using GIS were effective in presenting areas suitable for green mussel; and can be easily understood (i.e. different colour classification). However, individual perceptions on environmental quality differ, hence suitability criteria are difficult to define (Boyd and Schmittou, 1999) resulting in the ineffective use of GIS as a tool.
These GIS-based models have already served its purpose of identifying suitable sites for cultivation using primary biological information in other commodities. Despite the limitations of GIS, it is still considered an effective planning tool in indicating sustainable and suitable locations for aquaculture proven by Longdill et al. (2008) and supported by this study.

In general, Cañas Bay offers relatively suitable conditions for green mussel growth. Nevertheless, the evaluated area needs to be properly allocated and restriction zones must be identified as part of the coastal zone management. With the massive increase of digital information and appreciation of geospatial techniques as a tool for resource management, the results in this study will serve as a basis for suitability assessment that can determine new expansion for green mussel culture.

\section{Conclusion}

This study developed a GIS-based site classification and multi-criterion decision evaluation tool to identify mussel culture expansion areas. Using GIS in this study, Cañas Bay, lloilo was identified as a potential expansion area for green mussel Perna viridis culture based on physico-chemical parameters which were further validated by the significant increase in growth of Perna viridis. Further, this study suggested the use of GIS in criteria development and site suitability assessment for green mussel and in developing outputs such as thematic maps viable for effective aquaculture management for the use of researchers and policymakers. This study recommends integrating other factors such as food availability, socio-political, and economic parameters in the model that will result to the rational use of the coastal space yielding to the potential increase in the green mussel production.

\section{Acknowledgements}

This study was funded by the Department of Science and Technology - Philippines Council for Agriculture Aquatic and Natural Resources Research Division (DOST-PCAARRD). Gratitude to STRIDE-START Program for the support in preparing the manuscript.

\section{References}

Acosta V., Montes, M., Cortez, R., Guevera, M., Lodejros, C. 2012. Growth and survival of the green mussel $P$. viridis (Bivalvia: Mytilidae) in bottom culture conditions in Turpialito, Golfo de Cariaco, Venezuela. Revista de Biologia Tropical 60:1749-1762.

Adeleke 0.0., Jimoh, Y.A., Ayanshola, A.M., Aremu, A.S. 2013. Role of geomatics in the management of disasters and infrastructural failures. Ethiopian Journal of Environmental Studies and Management 6:143-148. https://dx.doi.org/10.4314/ejesm.v6i2.4

Aguilar-Manjarrez J., Ross, L.G. 1995. Geographical information system (GIS) environmental models for aquaculture development in Sinaloa 
state, Mexico. Aquaculture International 3:103-115. https://doi.org /10.1007/BF00117877

Anderson, D.M. 1989. Toxic algal blooms and red tides: a global perspective. In: Red Tides: Biology environmental science toxicology, Okaicki, T., Anderson, D.M., Nemoto, T. (Eds.), Elsevier, New York, pp. 11-16.

Aypa, S.M. 1990. Mussel culture. In: Regional sea farming development and demonstration project (RAS), selected papers on mollusc culture. UNDP/FAO (RAS/90/002). National Inland Fisheries Institute, Kasetsart University Campus Bangkhen, Bangkok, pp. 19-26.

Baumiller, T.K., Mooi, R., Messing, C.G. 2008. Urchins in the meadow: paleobiological and evolutionary implications of cidaroid predation on crinoids. Paleobiology 34:22-34. https://doi.org/10.1666/07031.1

Bendell, L.I., Wan, P.C.Y. 2011. Application of aerial photography in combination with GIS for coastal management at small spatial scales: a case study of shellfish aquaculture. Journal of Coastal Conservation 15:417-431. https://doi.org/10.1007/s11852-010-0101-8

Benson, A.J., Marelli, D., Frischer, M., Danforth, J.M., Williams, J.D. 2001. Establishment of the green mussel, Perna viridis (Linnaeus 1758) (Mollusca: Mytilidae) on the West Coast of Florida. Journal of Shellfish Research 20:21-29.

Boyd, C.E., Schmittou, H.R. 1999. Achievement of sustainable aquaculture through environmental management. Aquaculture Economics and Management 3:59-69. https://doi.org/10.1080 $\underline{113657309909380233}$

Buitrago, J., Rada, M., Hernandez, H.A., Buitrago, E. 2005. A single-use site selection technique, using GIS, for aquaculture planning: choosing locations for mangrove oyster raft culture in Margarita Island, Venezuela. Journal of Environmental Management 35:544556. https://doi.org/10.1007/s00267-004-0087-9

Cheong, L., Chen, F.Y. 1980. Preliminary studies on raft method of culturing green mussels, Perna viridis (L.), in Singapore. Singapore Journal of Primary Industries 8:119-133.

Chung, K.S., Acuña, A. 1981. Upper temperature tolerance limit of mussel Perna perna. Bulletin of the Japanese Society of Scientific Fisheries 47:441.

Clevenger, A., Wierzchowski, J., Chruszcz, B., Gunson, K. 2002. GISgenerated, expert-based models for identifying wildlife habitat linkages and planning mitigation passages. Conservation Biology 16:503-514. https://doi.org/10.1046/j.1523-1739.2002.00328.x

Close, C.H., Brent Hall, G. 2006. A GIS-based protocol for the collection and use of local knowledge in fisheries management planning. Journal of Environmental Management 78:341-352. https://doi.org /10.1016/j.jenvman.2005.04.027

Coeroli, M., de Gaillande, D., Landret, J.P., AQUACOP (D. Coatanea). 1984. Recent innovations in cultivation of molluscs in French Polynesia. Aquaculture 39:45-67. https://doi.org/10.1016/00448486(84)90258-8

de Graaf, G. and Jenness J. 2003. Geographic information systems in fisheries management and planning. FAO Fisheries Technical Paper. $499 \mathrm{pp}$.

Dineshbabu, A. P., Thomas, S. and Dinesh, A.C. 2015. GIS for assessing spatiotemporal variations in trawl bycatch off Mangalore coast. Fishery Technology 52:152-156.

Firth, L.B., Knights, A.M., Bell, S.S. 2011. Air temperature and winter mortality: implications for the persistence of the invasive mussel, Perna viridis in the intertidal zone of the south-eastern United States. Journal of Experimental Marine Biology and Ecology 400:250-256. https://doi.org/10.1016/j.jembe.2011.02.007

Google Earth. 2015. Sampling points in Cañas Bay, Philippines represented by landmarks. (Accessed 01 April 2015).
Ingole, N.A., Ram, R.N., Ranjan, R., Shankhwar, A.K. 2015. Advance application of geospatial technology for fisheries perspective in Tarai region of Himalayan state of Uttarakhand. Sustainable Water Resources Management 1:181-187. https://doi.org/10.1007/s40899$\underline{015-0012-9}$

Layugan, E., Tabasin, J.P., Alejos, M. Pidoy, L. 2018. Growth performance of green mussel Perna viridis transplanted in Buguey Lagoon, Philippines. Acta Scientific Agriculture 2:43-47.

Longdill, P.C., Healy, T.R., Black, K.P. 2008. An integrated GIS approach for sustainable aquaculture management area site selection. Ocean and Coastal Management 51:612-624. https://doi.org/10.1016 /j.ocecoaman.2008.06.010

McFarland, K., Jean, F., Thebault, J., Volety, A. 2014. Potential impacts of blooms of the toxic dinoflagellate Karenia brevis on the growth, survival and juvenile recruitment of the non-native green mussel Perna viridis in southeastern United States. Toxicon 109:94-102. https://doi.org/109:94-102.10.1016/j.toxicon.2015.11.017

Murawski, S.A., Wigley, S.E., Fogarty, M.J., Rago, P.J., Mountain, D.G. 2005. Effort distribution and catch patterns adjacent to temperate MPAs. ICES Journal of Marine Science 62:1150-1167.

Nath, S.S., Bolte, J.P., Ross, L.G., Aguilar-Manjarrez, J. 2000. Applications of geographical information systems (GIS) for spatial decision support in aquaculture. Aquacultural Engineering 23:233278. https://doi.org/10.1016/S0144-8609(00)00051-0

Philippine Statistics Authority. 2018. Fisheries situation report: January to December 2018 . $51 \quad$ pp https://www.bfar.da.gov.ph/2019/FSR2018Jan-DecRevisedV5.0.pdf

Rubec, P.J., Lewis, J., Reed, D., Westergren, C., Baumstark, R. 2009. An evaluation of the transferability of habitat suitability models between Tampa Bay and Charlotte Harbor, Florida. Florida Fish and Wildlife Conservation Commission, Fish and Wildlife Research Institute, St. Petersburg, Florida, USA. 73 pp.

Sallih, K. 2005. Mussel farming in the State of Sarawak, Malaysia: A feasibility study. United Nations University, Iceland. pp. 5-44.

Salmon, R., Kingzett, B. 2002. Profile and potential of the BC shellfish aquaculture industry. Kingzett Professional Services Ltd. for Vancouver Island Economic Developers Association, Delta, Nanaimo, British Colombia. 67 pp.

Saxby, S.A. 2002. A review of food availability: sea water characteristics and bivalve growth performance at coastal culture sites in temperate and warm temperate regions of the world. Environmental Science 132:1-44.

Segnini de Bravo, M.I., Chung, K.S., Perez, J.E. 1998. Salinity and temperature tolerances of the green and brown mussels, Perna viridis and Perna perna (Bivalvia: Mytilidae). Revista de Biologia Tropical 46 Supl. 5:121-125.

Silva, D.C.D., Lopes, A.B., Leite, F.A., Pinto, A., Silva, C.E.D. 2011. Definition of a component selection process based on OoS criteria and its application to self-adaptive software systems. Fifth Brazilian Symposium on Software Components, Architectures and Reuse, Sao Paulo, pp 90-99.

Sivalingam, P.M. 1977. Aquaculture of the green mussel, Mytilus viridis Linnaeus in Malaysia. Aquaculture 11:297-312. https://doi.org/10.1016/0044-8486(77)90079-5

Smaal, A.C. 2002. European mussel cultivation along the Atlantic coast: production status, problems and perspectives. Hydrobiologia 484:89-98. https://doi.org/10.1023/A:1021352904712

Sundaram, K.S., Shafee, M.S. 1989. Salinity tolerance of some bivalves of Ennore Estuary. Journal of Marine Biological Association of India 31:299-302.

Tan, K.S., Ransangan, J. 2014. A Review of Feeding Behavior, Growth, Reproduction and Aquaculture Site Selection for Green-Lipped 
Mussel, Perna viridis. Advances in Bioscience and Biotechnology 5:462-469. http://dx.doi.org/10.4236/abb.2014.55056

Tan, K.S., Ransangan, J. 2016. Feasibility of green mussel, Perna viridis Farming in Marudu Bay, Malaysia. Aquaculture Research 4:130-135. https://doi.org/10.1016/j.aqrep.2016.06.006

Travaglia, C., Profeti, G., Aguilar-Manjarrez, J., Lopez, N. 2004. Mapping coastal aquaculture and fisheries structures by satellite imaging radar. Case study of the Lingayen Gulf, the Philippines. Food and Agriculture Organization of the United Nations. Technical Paper. 58 pp. https://doi.org/10.13140/RG.2.1.4243.5928

Trondillo, M.J.F., Grace, B.D., Generalao, I.C. 2016. Geographic information system for upscaling the seaweed industry operation in two areas in Mindanao, Southern Philippines. Xavier University. http://ojs.upmin.edu.ph/index.php/banwa-suppl/article/view/259

(Accessed 15 June 2018).

Vakily, J.M. 1989. The biology and culture of mussels of the Genus Perna. International Center for Living Aquatic Resources Management, Manila, Philippines and Deutsche Gesellschaft for Technische Zusammenarbeit (GTZ) GmbH, Eschborn, Federal Republic of Germany. ICLARM Studies and Reviews 17:1-63.

Vincenzi, S., Caramori, G., Rossi, R., de Leo, G. 2006. A GIS-based habitat suitability model for commercial yield estimation of Tapes philippinarum in a Mediterranean coastal lagoon (Sacca di Goro, Italy). Ecological Modelling 193:90-104. https://doi.org/10.1016 lj.ecolmodel.2005.07.039

White, P., Phillips, M.J., Beveridge, M.C.M. 2013. Environmental impact, site selection and carrying capacity estimation for small-scale aquaculture in Asia. In: Site selection and carrying capacities for inland and coastal aquaculture, Ross, L.G., Telfer, T.C., Falconer, L., Soto, D. Aguilar-Manjarrez, J. (Eds.), pp. 231-251, FAO, Rome/Institute of Aquaculture, University of Stirling, the United Kingdom of Great Britain and Northern Ireland.

Wong, W.H., Cheung, S.G. 2003. Site-related differences in the feeding physiology of the green mussel Perna viridis: a reciprocal transplantation experiment. Marine Ecology Progress Series 258:147-159. https://doi.org/10.3354/meps258147 